\title{
Oxytocin and social salience: a call for gene-environment interaction research
}

\author{
Benjamin A. Tabak* \\ Department of Psychology, University of California, Los Angeles, Los Angeles, CA, USA \\ ${ }^{*}$ Correspondence: btabak@psych.ucla.edu \\ Edited by: \\ Alfonso Abizaid, Carleton University, Canada
}

Keywords: oxytocin, oxytocin receptor gene, OXTR, gene-environment interaction, genetic association study

\section{A commentary on}

A paradoxical association of an oxytocin receptor gene polymorphism: early-life adversity and vulnerability to depression by McQuaid, R. J., McInnis, O. A., Stead, J. D., Matheson, K., and Anisman, H. (2013). Front. Neurosci. 7:128. doi: 10.3389/fnins.2013.00128

The role of the neuropeptide oxytocin in social cognition and prosocial behavior continues to fascinate the scientific community (Bartz et al., 2011b). However, as our knowledge of oxytocin's influence on social processes increases, a more complex picture continues to emerge. Studies have begun to identify individual differences and environmental contexts that substantially alter the effects of oxytocin administration (Bartz et al., 2011b; Macdonald, 2012). In addition, interpersonal distress has been positively correlated with plasma oxytocin (e.g., Tabak et al., 2011), and evidence for potential negative consequences of oxytocin administration continues to accumulate (Miller, 2013) calling into question the view that oxytocin represents a social panacea (Pfeiffer, 2013). Although questions remain about how to properly measure oxytocin (Szeto et al., 2011; McCullough et al., 2013), and whether intranasal administration of oxytocin crosses the blood-brain barrier (Churchland and Winkielman, 2012; but see, Neumann et al., 2013), a developing theme in human oxytocin research is that early environmental experiences and/or attachment styles appear to moderate the effects of oxytocin administration (Bartz et al., 2010, 2011a; van IJzendoorn et al., 2011; De Dreu, 2012a; Riem et al., 2013).

Translational research has demonstrated that early environmental experiences can alter the oxytocin system (Champagne et al., 2001; Bales and Perkeybile, 2012), which may have longlasting effects that impact adult human functioning (e.g., Heim et al., 2009; Strathearn et al., 2009; Feldman et al., 2013). Based on findings such as these, an increasing number of studies have begun to investigate how variation on the gene encoding for the oxytocin receptor (OXTR) may relate to socially relevant normative and pathological phenotypes. To date, the most commonly studied marker on OXTR is rs53576, an adenine-to-guanine single nucleotide polymorphism (SNP) that lies in the third intronic region. Although most published studies have found associations with the rs53576 G allele and beneficial aspects of social cognition and behavior (e.g., Saphire-Bernstein et al., 2011; Krueger et al., 2012), several studies have found no relationship between rs53576 genotype and similar social phenotypes (e.g., Apicella et al., 2010; Cornelis et al., 2012; Tabak et al., 2013), or opposite relationships (i.e., where the A allele is protective; Costa et al., 2009). Although some of these discrepancies likely result from known issues in genetic association studies (e.g., Ioannidis et al., 2001; Lin et al., 2007), findings from studies of endogenous oxytocin (Strathearn et al., 2009), oxytocin administration (van IJzendoorn et al., 2011), and OXTR (McQuaid et al., 2013) suggest that one method through which studies might yield more consistent findings is to include measures of environmental experiences in order to examine gene-environment interactions.

In a study recently published in this journal, McQuaid et al. (2013) examined how rs53576 genotype moderated the relationship between childhood maltreatment and depression symptoms in a racially/ethnically diverse sample. The authors found an association between individuals who carried the $G$ allele on rs53576 and increased depression symptomology compared to those with the AA genotype. Furthermore, the authors discovered a meditational role of distrust/cynicism, suggesting that depression symptoms resulted (or co-occurred) in part from developing a distrustful attitude toward others after having suffered childhood maltreatment. McQuaid et al.'s (2013) findings are in agreement with Bradley et al. (2011) who studied a larger sample $(n=595)$ of $18-90$ year old African Americans with low-incomes: they found that individuals with the GG genotype on rs53576 who experienced severe childhood maltreatment were more likely to have disorganized attachment styles and higher levels of emotional dysregulation.

Thus, in contrast to the majority of published studies focusing on rs53576, Bradley et al. (2011) and McQuaid et al. (2013) found that it was the G allele that represented risk rather than protection when examined in the context of childhood maltreatment. Initially, these findings seem to contradict those from previous studies; however, these results are in agreement with the "social salience" hypothesis of oxytocin, which proposes that oxytocin increases the salience of both positive and negative social cues (ShamayTsoory et al., 2009). Following this logic, enhanced social salience may improve social cognition and increase prosocial behavior for individuals in positive environments, but have detrimental effects for others in negative environments (Bartz et al., 2011b; Bakermans-Kranenburg and van IJzendoorn, 2013), perhaps because these environments encourage 
the view that others are untrustworthy (Bakermans-Kranenburg et al., 2012). This hypothesis has gained some traction in light of recent findings demonstrating that oxytocin does not promote (or reduces) prosocial tendencies toward anonymous others or out-group members (Declerck et al., 2010; De Dreu et al., 2010; Radke and de Bruijn, 2012). However, the ways in which oxytocin administration may differentially affect people depending on attachment anxiety and/or avoidance continue to be explored (Bartz, 2012; De Dreu, 2012b).

Findings from Bradley et al. (2011) and McQuaid et al. (2013) involving rs53576 are also in agreement with the differential susceptibility hypothesis (Belsky et al., 2009), which posits that certain genetic variants can represent risk or protection depending upon whether or not the environment is positive or negative (for a discussion of differential susceptibility as related to another OXTR SNP, rs2254298, see Brüne, 2012). Importantly, the function of rs53576 is unknown. In addition, results from McQuaid et al. (2013) were based on a cross-sectional design, retrospective self-reports, and a small heterogeneous sample, which increases the potential for false-positive findings (Moffitt et al., 2006). As a result, the authors appropriately note that replication with larger samples and more sophisticated methodology is needed. Nonetheless, results from McQuaid et al. (2013) are in agreement with studies demonstrating the plasticity of the oxytocin system in both animals and humans and suggest that it is in the best interest of researchers investigating genetic associations (as well as epigenetic mechanisms; Kumsta et al., 2013) in oxytocin system relevant genes to measure both positive and negative environmental experiences for the purpose of examining gene-environment interactions.

\section{ACKNOWLEDGMENTS}

A postdoctoral fellowship for the author was supported by an NIMH training grant in Biobehavioral Issues in Physical and Mental Health at the University of California, Los Angeles (T32 MH015750). The author thanks Dr. Michael E. McCullough and Dr. Naomi I. Eisenberger for their helpful comments on a previous version of the manuscript.

\section{REFERENCES}

Apicella, C. L., Cesarini, D., Johannesson, M., Dawes, C. T., Lichtenstein, P., Wallace, B., et al. (2010). No association between oxytocin receptor (OXTR) gene polymorphisms and experimentally elicited social preferences. PLOS ONE 5:e11153. doi: 10.1371/journal.pone.0011153

Bakermans-Kranenburg, M. J., and van IJzendoorn, M. H. (2013). Sniffing around oxytocin: review and meta-analyses of trials in healthy and clinical groups with implications for pharmacotherapy. Transl. Psychiatry 3, e258. doi: 10.1038/tp.2013.34

Bakermans-Kranenburg, M. J., van Ijzendoorn, M. H., Riem, M. M., Tops, M., and Alink, L. R. (2012). Oxytocin decreases handgrip force in reaction to infant crying in females without harsh parenting experiences. Soc. Cogn. Affect. Neurosci. 7, 951-957. doi: 10.1093/scan/nsr067

Bales, K. L., and Perkeybile, A. M. (2012). Developmental experiences and the oxytocin receptor system. Horm. Behav. 61, 313-319. doi: 10.1016/j.yhbeh.2011.12.013

Bartz, J. A. (2012). Oxytocin, attachment, betrayal and self-interest: a commentary on "Oxytocin modulates the link between adult attachment and cooperation through reduced betrayal aversion" by Carsten, K. W. De Dreu, Psychoneuroendocrinology, Psychoneuroendocrinology 37, 1106-1108. doi: 10.1016/j.psyneuen.2011.10.003

Bartz, J. A., Simeon, D., Hamilton, H., Kim, S., Crystal, S., Braun, A., et al. (2011a). Oxytocin can hinder trust and cooperation in borderline personality disorder. Soc. Cogn. Affect. Neurosci. 6, 556-563. doi: 10.1093/scan/nsq085

Bartz, J. A., Zaki, J., Bolger, N., and Ochsner, K. N. (2011b). Social effects of oxytocin in humans: context and person matter. Trends Cogn. Sci. 15, 301-309. doi: 10.1016/j.tics.2011.05.002

Bartz, J. A., Zaki, J., Ochsner, K. N., Bolger, N., Kolevzon, A., Ludwig, N., et al. (2010). Effects of oxytocin on recollections of maternal care and closeness. Proc. Natl. Acad. Sci. U.S.A. 107, 21371-21375. doi: 10.1073/pnas.1012669107

Belsky, J., Jonassaint, C., Pluess, M., Stanton, M., Brummett, B., and Williams, R. (2009). Vulnerability genes or plasticity genes. Mol. Psychiatry 14, 746-754. doi: 10.1038/mp.2009.44

Bradley, B., Westen, D., Mercer, K. B., Binder, E. B., Jovanovic, T., Crain, D., et al. (2011). Association between childhood maltreatment and adult emotional dysregulation in a low-income, urban, African American sample: moderation by oxytocin receptor gene. Dev. Psychopathol. 23, 439-452. doi: 10.1017/S0954579411000162

Brüne, M. (2012). Does the oxytocin receptor (OXTR) polymorphism (rs2254298) confer vulnerability for psychopathology or differential susceptibility. Insights from evolution. BMC Medicine 10:38. doi: 10.1186/1741-7015-10-38

Champagne, F., Diorio, J., Sharma, S., and Meaney, M. J. (2001). Naturally occurring variations in maternal behavior in the rat are associated with differences in estrogen-inducible central oxytocin receptors. Proc. Natl. Acad. Sci. U.S.A. 98, 12736-12741. doi: 10.1073/pnas. 221224598

Churchland, P. S., and Winkielman, P. (2012). Modulating social behavior with oxytocin: how does it work. What does it mean? Horm. Behav. 61, 392-399. doi: 10.1016/j.yhbeh.2011.12.003

Cornelis, M. C., Glymour, M. M., Chang, S. C., Tchetgen, E. J., Liang, L., Koenen, K. C., et al. (2012). Oxytocin receptor (OXTR) is not associated with optimism in the Nurses' Health Study. Mol. Psychiatry 17, 1157-1159. doi: 10.1038/mp.2011.178

Costa, B., Pini, S., Gabelloni, P., Abelli, M., Lari, L., Cardini, A., et al. (2009). Oxytocin receptor polymorphisms and adult attachment style in patients with depression. Psychoneuroendocrinology 34, 1506-1514. doi:10.1016/j.psyneuen.2009.05.006

Declerck, C. H., Boone, C., and Kiyonari, T. (2010). Oxytocin and cooperation under conditions of uncertainty: the modulating role of incentives and social information. Horm. Behav. 57, 368-374. doi: 10.1016/j.yhbeh.2010.01.006

De Dreu, C. K. (2012a). Oxytocin modulates the link between adult attachment and cooperation through reduced betrayal aversion. Psychoneuroendocrinology 37, 871-880. doi: 10.1016/j.psyneuen.2011.10.003

De Dreu, C. K. (2012b). Oxytocin, attachment, and self-regarding preferences in humans: rejoinder to Bartz. Psychoneuroendocrinology 37, 1108-1110. doi: 10.1016/j.psyneuen.2012.03.004

De Dreu, C. K., Greer, L. L., Handgraaf, M. J., Shalvi, S., Van Kleef, G. A., Baas, M., et al. (2010). The neuropeptide oxytocin regulates parochial altruism in intergroup conflict among humans. Science 328, 1408-1411. doi: 10.1126/science. 1189047

Feldman, R., Gordon, I., Influs, M., Gutbir, T., and Ebstein, R. P. (2013). Parental oxytocin and early caregiving jointly shape children's oxytocin response and social reciprocity. Neuropsychopharmacology 38, 1154-1162. doi: 10.1038/npp.2013.22

Heim, C., Young, L. J., Newport, D. J., Mletzko, T., Miller, A. H., and Nemeroff, C. B. (2009). Lower CSF oxytocin concentrations in women with a history of childhood abuse. Mol. Psychiatry 14, 954-958. doi: 10.1038/mp.2008.112

Ioannidis, J. P., Ntzani, E. E., Trikalinos, T. A., and Contopoulos-Ioannidis, D. G. (2001). Replication validity of genetic association studies. Nat. Genet. 29, 306-309. doi: 10.1038/ng749

Krueger, F., Parasuraman, R., Iyengar, V., Thornburg, M., Weel, J., Lin, M., et al. (2012). Oxytocin receptor genetic variation promotes human trust behavior. Front. Hum. Neurosci. 6:4. doi: 10.3389/fnhum.2012.00004

Kumsta, R., Hummel, E., Chen, F. S., and Heinrichs, M. (2013). Epigenetic regulation of the oxytocin receptor gene: implications for behavioral neuroscience. Front. Neurosci. 7:83. doi: 10.3389/fnins.2013.00083

Lin, P. I., Vance, J. M., Pericak-Vance, M. A., and Martin, E. R. (2007). No gene is an island: the flip-flop phenomenon. Am. J. Hum. Genet. 80, 531-538. doi: 10.1086/512133

Macdonald, K. S. (2012). Sex, receptors, and attachment: a review of individual factors influencing response to oxytocin. Front. Neurosci. 6:194. doi: $10.3389 /$ fnins.2012.00194

McCullough, M. E., Churchland, P. S., and Mendez, A. J. (2013). Problems with measuring peripheral 
oxytocin: can the data on oxytocin and human behavior be trusted? Neurosci. Biobehav. Rev 37, 1485-1492. doi: 10.1016/j.neubiorev.2013. 04.018

McQuaid, R. J., McInnis, O. A., Stead, J. D., Matheson, K., and Anisman, H. (2013). A paradoxical association of an oxytocin receptor gene polymorphism: early-life adversity and vulnerability to depression. Front. Neurosci. 7:128. doi: 10.3389/fnins.2013.00128

Miller, G. (2013). The promise and perils of oxytocin. Science 339, 267-269. doi: 10.1126/science.339.6117.267

Moffitt, T. E., Caspi, A., and Rutter, M. (2006). Measured gene-environment interactions in psychopathology: concepts, research strategies, and implications for research, intervention, and public understanding of genetics. Perspect. Psychol. Sci. 1, 5-27. doi: 10.1111/j.1745-6916. 2006.00002.x

Neumann, I. D., Maloumby, R., Beiderbeck, D. I., Lukas, M., and Landgraf, R. (2013). Increased brain and plasma oxytocin after nasal and peripheral administration in rats and mice. Psychoneuroendocrinology 38, 1985-1993. doi: 10.1016/j.psyneuen.2013.03.003

Pfeiffer, U. J. (2013). Oxytocin-not always a moral molecule. Front. Hum. Neurosci. 6:193. doi: 10.3389/fnhum.2013.00010

Radke, S., and de Bruijn, E. R. (2012). The other side of the coin: oxytocin decreases the adherence to fairness norms. Front. Hum. Neurosci. 6:193. doi: 10.3389/fnhum.2012.00193
Riem, M. E. M., van IJzendoorn, M. H., Tops, M., Boksem, M. A. S., Rombouts, S. A. R. B., and Bakermans-Kranenburg, M. J. (2013). Oxytocin effects on complex brain networks are moderated by experiences of maternal love withdrawal. Eur. Neuropsychopharmacol. 10, 1288-1295. doi: 10.1016/j.euroneuro.2013.01.011

Saphire-Bernstein, S., Way, B. M., Kim, H. S. Sherman, D. K., and Taylor, S. E. (2011). Oxytocin receptor gene (OXTR) is related to psychological resources. Proc. Natl. Acad. Sci. U.S.A. 108 15118-15122. doi: 10.1073/pnas.1113137108

Shamay-Tsoory, S. G., Fischer, M., Dvash, J., Hariri, A. R., Perach-Bloom, N., and Levkovitz, Y. (2009). Intranasal administration of oxytocin increases envy and schadenfreude (gloating). Biol. Psychiatry 66, 864-870. doi: 10.1016/j.biopsych. 2009.06.009

Strathearn, L., Fonagy, P., Amico, J., and Montague, P. R. (2009). Adult attachment predicts maternal brain and oxytocin response to infant cues. Neuropsychopharmacology 34, 2655-2666. doi: 10.1038/npp.2009.103

Szeto, A., McCabe, P. M., Nation, D. A., Tabak, B. A., Rossetti, M. A., McCullough, M. E., et al. (2011). Evaluation of enzyme immunoassay and radioimmunoassay methods for the measurement of plasma oxytocin. Psychosom. Med. 73, 393-400. doi: 10.1097/PSY.0b013e31821df0c2

Tabak, B. A., McCullough, M. E., Carver, C. S., Pedersen, E. J., and Cuccaro, M. L. (2013). Variation in oxytocin receptor gene (OXTR) polymorphisms is associated with emotional and behavioral reactions to betrayal. Soc. Cogn. Affect. Neurosci. doi: 10.1093/scan/nst042. [Epub ahead of print].

Tabak, B. A., McCullough, M. E., Szeto, A., Mendez, A. J., and McCabe, P. M. (2011). Oxytocin indexes relational distress following interpersonal harms in women. Psychoneuroendocrinology 36, 115-122. doi: 10.1016/j.psyneuen.2010.07.004

van IJzendoorn, M. H., Huffmeijer, R., Alink, L. R., Bakermans-Kranenburg, M. J., and Tops, M. (2011). The impact of oxytocin administration on charitable donating is moderated by experiences of parental love-withdrawal. Front. Psychol. 2:258. doi: 10.3389/fpsyg.2011.00258

Received: 04 October 2013; accepted: 10 October 2013; published online: 31 October 2013.

Citation: Tabak BA (2013) Oxytocin and social salience: a call for gene-environment interaction research. Front. Neurosci. 7:199. doi: 10.3389/fnins.2013.00199

This article was submitted to Neuroendocrine Science, a section of the journal Frontiers in Neuroscience.

Copyright (c) 2013 Tabak. This is an open-access article distributed under the terms of the Creative Commons Attribution License (CC BY). The use, distribution or reproduction in other forums is permitted, provided the original author(s) or licensor are credited and that the original publication in this journal is cited, in accordance with accepted academic practice. No use, distribution or reproduction is permitted which does not comply with these terms. 